\title{
How reliable is the Alvarado score in acute appendicitis?
}

\author{
Yücel Yüksel, M.D.,, ${ }^{1}$ Bülent Dinç, M.D., ${ }^{2}$ Deniz Yüksel, M.D., ${ }^{3}$ \\ Selcan Enver Dinç, M.D., ${ }^{4}$ Ayhan Mesci, M.D. ${ }^{5}$
}

\begin{abstract}
${ }^{1}$ Department of General Surgery, Tatvan State Hospital, Bitlis; ${ }^{2}$ Department of General Surgery, Atatürk State Hospital, Antalya; ${ }^{3}$ Department of Anaesthesiology, Tatvan State Hospital, Bitlis; ${ }^{4}$ Department of Emergency Medicine, Akdeniz University Faculty of Medicine, Antalya; ${ }^{5}$ Department of General Surgery, Akdeniz University Faculty of Medicine, Antalya
\end{abstract}

\begin{abstract}
BACKGROUND: We aimed to investigate the reliability of the Alvarado score (AS) in determining acute appendicitis and the different parameters that affect the AS.

METHODS: Three hundred and thirteen patients suspected of acute appendicitis (AA) aged 18-70 years were included in this study. Patient data including AS calculated from emergency services and at discharge, follow-up, and operations were recorded. Patients were divided into three groups according to the AS, as AS <4, AS 5-7 and AS 8-10. AA and appendicitis perforation rates were compared according to the different parameters.
\end{abstract}

RESULTS: The mean age of patients ( $55 \%$ females, $45 \%$ males) was $30.8 \pm 10.8$ years. The AA (appendix perforation) rates of 21 I patients who underwent operation were found as: AS $\leq 4: 56.5 \%$ (7.7\%), AS 5-7: 75.9\% (10\%), and AS 8- 10: $89 \%$ (27.8\%). The percentage of negative appendectomy was $19.4 \%$. The scoring was more reliable in males with AS $5-7$, and the reliability weakened as body mass index (BMI) increased in all groups.

CONCLUSION: Patients with AS $\leq 4$ must be followed up and should be informed at the time of their discharge about the slight possibility of appendicitis. The effect of AS in determining the diagnosis of appendicitis is not influenced by age or symptom duration.

Key words: Alvarado score; appendicitis; diagnosis; perforation.

\section{INTRODUCTION}

Acute appendicitis (AA) is one of the most common emergent surgical conditions. It accounts for $1 \%$ of abdominal surgeries. ${ }^{[1-3]}$ Attempts at the diagnosis of $A A$ are made by anamnesis, physical examination, laboratory analyses, and imaging methods. ${ }^{[4,5]}$ Since appendicitis may lead to morbidity and mortality unless treated, surgery is mandatory in cases with a possible diagnosis of appendicitis. ${ }^{[2,6]}$ It is difficult to

Address for correspondence: Bülent Dinç, M.D.

Antalya Atatürk Devlet Hastanesi, Anafartalar Caddesi, 07040 Antalya, Turkey

Tel: +90 242 - 3454550 E-mail: bulent1999@yahoo.com

Qucik Response Code

Ulus Travma Acil Cerr Derg

20|4;20(I):12-18

doi: $10.5505 /$ tjtes.2014.60569

Copyright 2014

TJTES make a definite diagnosis of appendicitis despite the current advanced imaging methods. Prevalence of a clinically correct diagnosis of AA is approximately $85 \% .^{[5]}$ Lower prevalence rates lead to unnecessary surgeries; therefore, the differential diagnosis should be made precisely. ${ }^{[7]}$

It is known that diagnostic interventions dramatically reduce the number of appendectomies among patients without appendicitis, the prevalence of perforation, and the duration of their hospital stay. Diagnostic methods used for the diagnosis of appendicitis include scoring systems, computer programs, ultrasonography (US), computed tomography (CT), magnetic resonance (MR), and laparoscopy. ${ }^{[2,5,8]}$

Among the scoring systems, the Alvarado score (AS) is a well-tested, extensively experienced, 10-point clinical scoring system. This scoring system consists of anamnesis, physical examination findings and laboratory results. ${ }^{[2,4,5]}$ The AS is a reliable, cheap and reproducible tool for the diagnosis of $A A$ in the emergency room. ${ }^{[9]}$ 
Many prospective studies have reported that while AS alone is an inadequate test, it can be used effectively to specify those patients that require scanning. ${ }^{[2,5]}$

The AS for the diagnosis of AA comprises many components, as shown in Table I. Many studies have recommended that patients with AS $<4$ can be discharged, while those with scores of 5-7 should be followed, and those with scores $>7$ should undergo surgery. ${ }^{[2,4,5]}$

This present study investigated to what extent the efficacy of the AS in detecting AA is influenced by age, gender, body mass index (BMI), and symptom duration, as well as the prevalences of $A A$ in patients with low AS, negative appendectomy and perforation.

\section{MATERIALS AND METHODS}

The present study, which was performed after obtaining approval of the local ethical committee, included $3 \mid 3$ patients aged 18-70 years, who applied to the Emergency Unit of Akdeniz University Hospital between March 2007 and May 2009. Pregnant women, transplant patients, and patients with known malignancy, median laparotomy, and palpable mass were all excluded from the study. Treatment was planned by the relevant physician independent of the AS.

Patients were divided into three groups according to the AS, as: I-4 (low risk), 5-7 (moderate risk) and 8-10 (high risk). The groups were compared in terms of age ( $\leq 40$ years [incidence more than] $/>40$ years [incidence less than]), gender (male/ female), BMI ( $\left.\leq 25 \mathrm{~kg} / \mathrm{m}^{2} />25 \mathrm{~kg} / \mathrm{m}^{2}\right)$, and symptom duration ( $\leq 24$ hours/>24 hours). Treatment of patients, as discharged, monitored or operated, was recorded. Patients who underwent surgery were grouped as AA or non-AA. We investigated whether or not the AS was influenced by age, gender, BMI, or symptom duration as well as its efficacy in detecting AA.

The Statistical Package for the Social Sciences (SPSS) for Windows 16.0 program was used for the statistical analyses of the study data. As well as descriptive statistical methods (mean, standard deviation), intergroup comparison of normally distributed parameters of the quantitative data was done by Student's t-test, whereas the Mann-Whitney U-test was used for the parameters not normally distributed. Relationships between numeric data were analyzed using correlation analysis. Qualitative data was compared by using the chi-square test. Results were evaluated within $95 \%$ confidence interval and at a P level less than 0.05 .

\section{RESULTS}

A total of 313 cases were included in the study between March 2007 and May 2009. Of these cases, 141 (45\%) were male and $172(55 \%)$ were female. The overall mean age was $30.8 \pm 10.8$ (I8-69) years. The mean age of males was 3I.I \pm 10.3 (I8-69) years and of females was $30.5 \pm 11.1$ (I8-69) years.
Table I. Components of the Alvarado score

\begin{tabular}{|c|c|c|}
\hline \multicolumn{2}{|l|}{ Alvarado Score } & Score \\
\hline \multicolumn{2}{|l|}{ Migration of pain } & 1 \\
\hline \multicolumn{2}{|l|}{ Anorexia } & I \\
\hline \multicolumn{2}{|l|}{ Nausea } & I \\
\hline \multicolumn{2}{|c|}{ Tenderness in right lower quadrant } & 2 \\
\hline \multicolumn{2}{|l|}{ Rebound pain } & I \\
\hline \multicolumn{2}{|c|}{ Elevated temperature $\left(>37.3^{\circ} \mathrm{C}\right)$} & I \\
\hline \multicolumn{2}{|c|}{ Leukocytosis $>10.000 / \mathrm{mm}^{3}$} & 2 \\
\hline \multicolumn{2}{|l|}{ Neutrophilia $>75 \%$} & I \\
\hline \multicolumn{2}{|l|}{ Total } & 10 \\
\hline $\begin{array}{c}\text { I-4 } \\
\text { Discharge } \\
\text { 30\% Appendicitis }\end{array}$ & \begin{tabular}{|c|}
$\mathbf{5 - 7}$ \\
Monitoring/Admission \\
66\% Appendicitis
\end{tabular} & $\begin{array}{c}\text { 8- } 10 \\
\text { Surgery } \\
\text { 93\% Appendicitis }\end{array}$ \\
\hline
\end{tabular}

One hundred and fifty-seven (50\%) of 313 patients underwent surgery after the first examination in the emergency room. Fifty-four (47.8\%) of I I 3 patients hospitalized for the follow-up underwent surgery after being monitored. AA was detected in $136(86.6 \%)$ of 157 patients and 34 (62.9\%) of 54 patients who underwent surgery directly or after being monitored, respectively (Figure I). Patients who had been discharged from the emergency room were called back for a physical examination after 24 hours. One of these patients had undergone surgery due to AA (without perforation) in an external center, whereas one patient presented with abdominal pain 12 hours after the examination in the emergency room; this patient underwent surgery and AA was detected.

$38.3 \%$ of patients with AS $<4$ and $0 \%$ of patients with AS 8-10 had been discharged directly from the emergency room (Table 2).

Among the 2 II patients that underwent surgery, $56.5 \%$ of AS $\leq 4$ patients had signs consistent with $A A$, whereas this ratio was $75.9 \%$ for AS $5-7$ patients and $89 \%$ for AS $8-10$ patients. The negative appendectomy rate (19.4\%) decreased in conjunction with an increase in the calculated AS (Table 3). Patients with negative appendectomy were identified as having genitourinary diseases (tuboovarian pathology, pelvic inflammatory disease, endometriosis), colonic diseases (Crohn disease, colonic perforation, colonic diverticulosis), psoas hematoma, and normal appendix.

Among patients with AS of 5-7, male patients were found more likely to have AA compared with females (Table 4).

There was no significant difference between AS and AA diagnosis according to the patient's age (Table 5). 


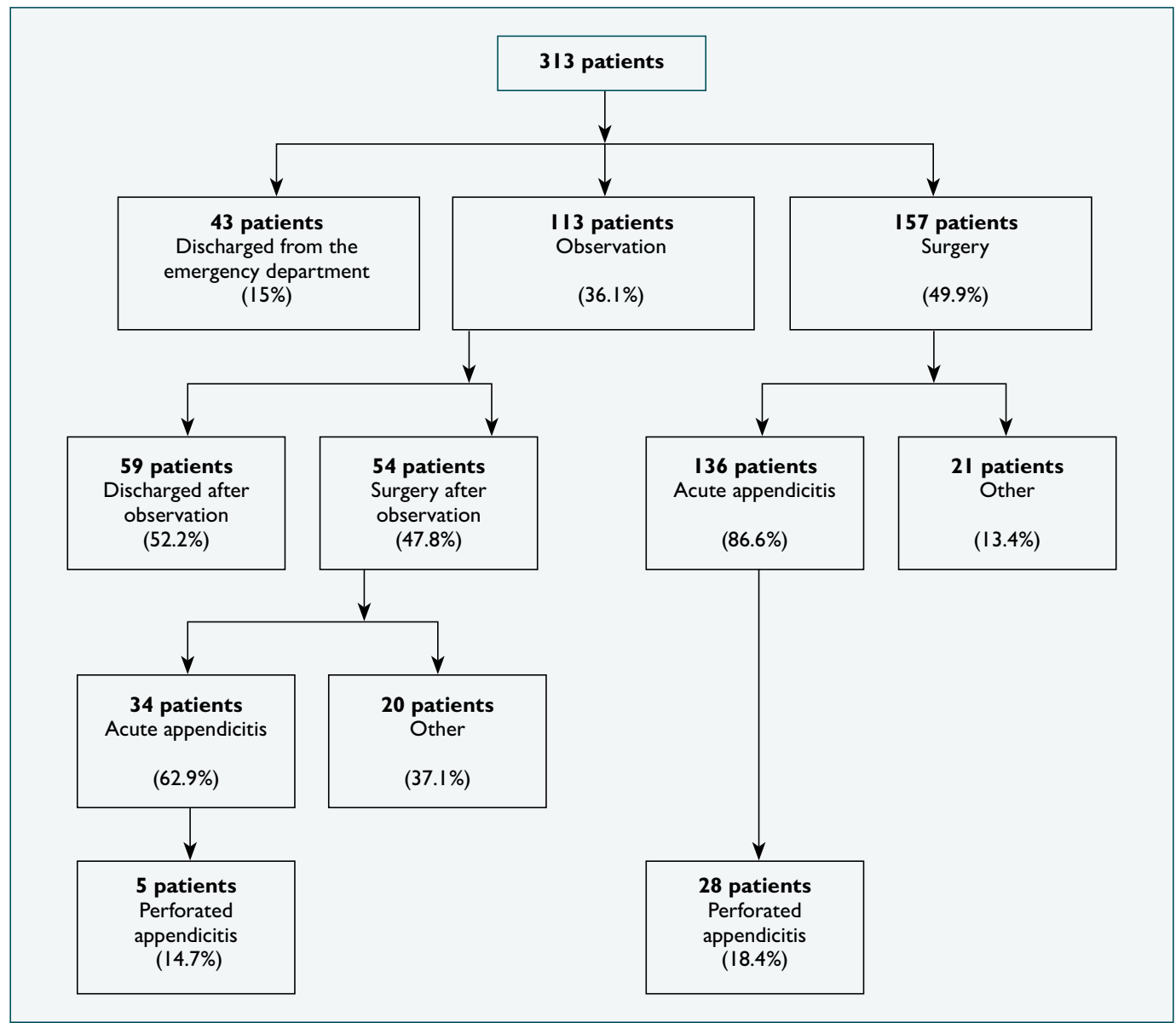

Figure 1. Distribution of the study patients.

Table 2. Distribution of the patients according to the Alvarado score

\begin{tabular}{|c|c|c|c|c|c|c|c|c|c|c|}
\hline \multirow[t]{2}{*}{$\begin{array}{l}\text { Alvarado } \\
\text { score }\end{array}$} & \multicolumn{2}{|c|}{ Discharged } & \multicolumn{2}{|c|}{$\begin{array}{l}\text { Discharged after } \\
\text { observation }\end{array}$} & \multicolumn{2}{|c|}{ Surgery } & \multicolumn{2}{|c|}{$\begin{array}{l}\text { Surgery after } \\
\text { observation }\end{array}$} & \multicolumn{2}{|c|}{ Total } \\
\hline & $n$ & $\%$ & $\mathbf{n}$ & $\%$ & $\mathrm{n}$ & $\%$ & $n$ & $\%$ & $n$ & $\%$ \\
\hline$\leq 4$ & 23 & 38.3 & 14 & 23.3 & 10 & 16.7 & 13 & 21.7 & 60 & 100 \\
\hline $5-7$ & 20 & 14.8 & 36 & 21.7 & 51 & 37.8 & 28 & 20.7 & 135 & 100 \\
\hline $8-10$ & 0 & 0 & 9 & 7.6 & 96 & $8 \mathrm{I} .4$ & 13 & 11.0 & 118 & 100 \\
\hline Total & 43 & 13.7 & 59 & 18.8 & 157 & 50.1 & 54 & 17.4 & 313 & 100 \\
\hline
\end{tabular}

Table 3. Distribution of surgical findings of the patients who underwent surgery according to the Alvarado score

\begin{tabular}{|c|c|c|c|c|c|c|c|}
\hline \multirow{3}{*}{$\begin{array}{l}\text { Alvarado } \\
\text { score }\end{array}$} & \multicolumn{6}{|c|}{ Results } & \multirow{3}{*}{$p$} \\
\hline & \multicolumn{2}{|c|}{ Appendicitis (-) } & \multicolumn{2}{|c|}{ Appendicitis (+) } & \multicolumn{2}{|c|}{ Total } & \\
\hline & $\mathbf{n}$ & $\%$ & $\mathbf{n}$ & $\%$ & $\mathbf{n}$ & $\%$ & \\
\hline$\leq 4$ & 10 & 43.5 & 13 & 56.5 & 23 & 100 & \\
\hline $5-7$ & 19 & 24.1 & 60 & 75.9 & 79 & 100 & \\
\hline $8-10$ & 12 & 11.0 & 97 & 89.0 & 109 & 100 & \\
\hline Total & 41 & 19.4 & 170 & 80.6 & 211 & 100 & $=0.001$ \\
\hline
\end{tabular}


Table 4. Distribution of patients according to gender and the Alvarado score

\begin{tabular}{|c|c|c|c|c|c|c|c|c|}
\hline \multirow{3}{*}{$\begin{array}{l}\text { Alvarado } \\
\text { score }\end{array}$} & \multirow{3}{*}{ Gender } & \multicolumn{6}{|c|}{ Results } & \multirow{3}{*}{$p$} \\
\hline & & \multicolumn{2}{|c|}{ Appendicitis (-) } & \multicolumn{2}{|c|}{ Appendicitis (+) } & \multicolumn{2}{|c|}{ Total } & \\
\hline & & $\mathbf{n}$ & $\%$ & $\mathbf{n}$ & $\%$ & $\mathbf{n}$ & $\%$ & \\
\hline \multirow[t]{3}{*}{$\leq 4$} & Female & 29 & 85.3 & 5 & 14.7 & 34 & 100 & \\
\hline & Male & 18 & 69.2 & 8 & 30.8 & 26 & 100 & \\
\hline & Total & 47 & 78.3 & 13 & 21.7 & 60 & 100 & $=0.119$ \\
\hline \multirow[t]{3}{*}{$5-7$} & Female & 55 & 73.3 & 20 & 26.7 & 75 & 100 & \\
\hline & Male & 20 & 33.3 & 40 & 66.7 & 60 & 100 & \\
\hline & Total & 75 & 55.6 & 60 & 44.4 & 135 & 100 & $<0.001$ \\
\hline \multirow[t]{3}{*}{$8-10$} & Female & 16 & 25.4 & 47 & 74.6 & 63 & 100 & \\
\hline & Male & 6 & 10.9 & 49 & 89.1 & 55 & 100 & \\
\hline & Total & 22 & 19.4 & 96 & 44.4 & 118 & 100 & $=0.55$ \\
\hline
\end{tabular}

Table 5. Distribution of patients according to age and the Alvarado score

\begin{tabular}{|c|c|c|c|c|c|c|c|c|}
\hline \multirow{3}{*}{$\begin{array}{l}\text { Alvarado } \\
\text { score }\end{array}$} & \multirow{3}{*}{ Age } & \multicolumn{6}{|c|}{ Results } & \multirow{3}{*}{$p$} \\
\hline & & \multicolumn{2}{|c|}{ Appendicitis (-) } & \multicolumn{2}{|c|}{ Appendicitis (+) } & \multicolumn{2}{|c|}{ Total } & \\
\hline & & $\mathbf{n}$ & $\%$ & $\mathbf{n}$ & $\%$ & $\mathbf{n}$ & $\%$ & \\
\hline \multirow[t]{3}{*}{$\leq 4$} & $\leq 40$ & 42 & 77.8 & 12 & 22.2 & 54 & 100 & \\
\hline & $>40$ & 5 & 83.4 & I & 16.6 & 6 & 100 & \\
\hline & Total & 47 & 78.3 & 13 & 21.7 & 60 & 100 & $=0.369$ \\
\hline \multirow[t]{3}{*}{$5-7$} & $\leq 40$ & 67 & 58.8 & 47 & 41.2 & 114 & 100 & \\
\hline & $>40$ & 8 & 38.1 & 13 & 61.9 & 21 & 100 & \\
\hline & Total & 75 & 55.6 & 60 & 44.4 & 135 & 100 & $=0.147$ \\
\hline \multirow[t]{3}{*}{$8-10$} & $\leq 40$ & 19 & 20.5 & 74 & 79.5 & 93 & 100 & \\
\hline & $>40$ & 3 & 22.0 & 22 & 88.0 & 25 & 100 & \\
\hline & Total & 22 & 18.7 & 96 & 81.3 & 118 & 100 & $=0.233$ \\
\hline
\end{tabular}

Table 6. Distribution of patients according to BMI and the Alvarado score

\begin{tabular}{|c|c|c|c|c|c|c|c|c|}
\hline \multirow{3}{*}{$\begin{array}{l}\text { Alvarado } \\
\text { score }\end{array}$} & \multirow{3}{*}{ BMI } & \multicolumn{6}{|c|}{ Results } & \multirow{3}{*}{$p$} \\
\hline & & \multicolumn{2}{|c|}{ Appendicitis (-) } & \multicolumn{2}{|c|}{ Appendicitis (+) } & \multicolumn{2}{|c|}{ Total } & \\
\hline & & $\mathbf{n}$ & $\%$ & $\mathbf{n}$ & $\%$ & $\mathbf{n}$ & $\%$ & \\
\hline \multirow[t]{3}{*}{$\leq 4$} & $\leq 25$ & 32 & 77.8 & 8 & 22.2 & 40 & 100 & \\
\hline & $>25$ & 15 & 83.4 & 5 & 16.6 & 20 & 100 & \\
\hline & Total & 47 & 78.3 & 13 & 21.7 & 60 & 100 & $=0.448$ \\
\hline \multirow[t]{3}{*}{$5-7$} & $\leq 25$ & 51 & 62.2 & 31 & 37.8 & 82 & 100 & \\
\hline & $>25$ & 24 & 45.3 & 29 & 54.7 & 53 & 100 & \\
\hline & Total & 75 & 62.3 & 60 & 37.7 & 135 & 100 & $=0.04$ \\
\hline \multirow[t]{3}{*}{$8-10$} & $\leq 25$ & 19 & 20.5 & 74 & 79.5 & 93 & 100 & \\
\hline & $>25$ & 3 & 22.0 & 22 & 88.0 & 25 & 100 & \\
\hline & Total & 22 & 18.7 & 96 & 81.3 & 118 & 100 & $=0.077$ \\
\hline
\end{tabular}

BMI: Body mass index. 
Table 7. Distribution of patients according to symptom duration and the Alvarado Score

\begin{tabular}{|c|c|c|c|c|c|c|c|c|}
\hline \multirow{3}{*}{$\begin{array}{l}\text { Alvarado } \\
\text { score }\end{array}$} & \multirow{3}{*}{$\begin{array}{l}\text { Duration of } \\
\text { symptoms }\end{array}$} & \multicolumn{6}{|c|}{ Results } & \multirow{3}{*}{$p$} \\
\hline & & \multicolumn{2}{|c|}{ Appendicitis (-) } & \multicolumn{2}{|c|}{ Appendicitis (+) } & \multicolumn{2}{|c|}{ Total } & \\
\hline & & $\mathbf{n}$ & $\%$ & $\mathbf{n}$ & $\%$ & $\mathbf{n}$ & $\%$ & \\
\hline \multirow[t]{3}{*}{$\leq 4$} & $\leq 24$ & 27 & 77.2 & 8 & 22.8 & 35 & 100 & \\
\hline & $>24$ & 20 & 80.0 & 5 & 20.0 & 25 & 100 & \\
\hline & Total & 47 & 78.3 & 13 & 21.7 & 60 & 100 & $=0.525$ \\
\hline \multirow[t]{3}{*}{$5-7$} & $\leq 24$ & 51 & 51.0 & 49 & 49.0 & 100 & 100 & \\
\hline & $>24$ & 24 & 68.6 & II & 31.4 & 35 & 100 & \\
\hline & Total & 75 & 62.3 & 60 & 37.7 & 135 & 100 & $=0.066$ \\
\hline \multirow[t]{3}{*}{$8-10$} & $\leq 24$ & 14 & 16.9 & 69 & 83.1 & 83 & 100 & \\
\hline & $>24$ & 8 & 22.9 & 27 & 77.1 & 35 & 100 & \\
\hline & Total & 22 & 18.7 & 96 & 81.3 & 118 & 100 & $=0.332$ \\
\hline
\end{tabular}

Table 8. Comparison between the Alvarado Score and appendix perforation

\begin{tabular}{|c|c|c|c|c|c|c|c|}
\hline \multirow{3}{*}{$\begin{array}{l}\text { Alvarado } \\
\text { score }\end{array}$} & \multicolumn{6}{|c|}{ Results } & \multirow{3}{*}{$p$} \\
\hline & \multicolumn{2}{|c|}{ Appendicitis (-) } & \multicolumn{2}{|c|}{ Appendicitis (+) } & \multicolumn{2}{|c|}{ Total } & \\
\hline & $\mathbf{n}$ & $\%$ & $\mathbf{n}$ & $\%$ & $\mathbf{n}$ & $\%$ & \\
\hline$\leq 4$ & 12 & 92.3 & 1 & 7.7 & 13 & 100 & \\
\hline $5-7$ & 54 & 90.0 & 6 & 10.0 & 60 & 100 & \\
\hline $8-10$ & 70 & 72.2 & 27 & 27.8 & 97 & 100 & \\
\hline Total & 136 & 80.0 & 34 & 20.0 & 170 & 100 & $=0.013$ \\
\hline
\end{tabular}

In the comparison of $\mathrm{BMI}$ in the patient group with AS 5-7, $37.8 \%$ of patients with $\mathrm{BMI} \leq 25$ and $54.7 \%$ of patients with $\mathrm{BMI}>25$ had appendicitis, and this difference was significant. An increase in BMI reduced the reliability of AS in all groups (Table 6).

There was no difference between groups in the comparison of the diagnosis of appendicitis by the AS according to the variation in symptom duration as more or less than 24 hours (Table 7).

In patients with AS $\leq 4$ and AS 5-7, the rates of perforated appendicitis were found as $7.7 \%$ and $27.8 \%$, respectively (Table 8). Accordingly, the incidence of perforation was seen to increase as the AS increased.

\section{DISCUSSION}

Acute appendicitis (AA) is the most common cause of acute abdomen in all age groups. Accurate and prompt diagnosis in those admitted to the emergency room with the preliminary diagnosis of AA remains problematic. ${ }^{[10]}$ Anamnesis and physical examination are the cornerstones of the diagnosis. ${ }^{[1]}$ The aim is to make an early and accurate diagnosis before the de- velopment of complications, thereby reducing the prevalence of negative appendectomy.

Studies in the literature have recommended hospital discharge for patients with $A S \leq 4 .^{[5,12]}$ In the study of Khan et al.., ${ }^{[13]}$ when patients with AS $\leq 4$ were divided into two as those discharged after monitoring (emergency room and surgery clinic) and those who underwent surgery, 17 of 100 patients were in the first group, and were discharged. Three of the patients returned within 48 hours and the new AS was calculated as 7; they underwent surgery and AA was detected (17\%). Winn et al. ${ }^{\left[{ }^{12]}\right.}$ discharged 12 patients $(9.8 \%)$ and offered no medical follow-up; 4 patients were re-admitted and 2 underwent surgery, but appendicitis was not found. In the present study, 37 patients with AS $\leq 4$ were discharged; 2 of them underwent surgery due to re-admittance, and AA was detected (5.4\%). With regard to the patients that underwent surgery with AS $\leq 4$, Yildirim et al. ${ }^{[5]}$ performed surgery in 14 patients, and detected AA in 13 (92.8\%). In the present study, 23 patients with AS $\leq 4$ underwent surgery, and AA was detected in $13(56.5 \%)$. The result was higher than that in the literature. We think that patients with $\mathrm{AS} \leq 4$ should be monitored; discharged patients should be informed about abdominal pain 
and asked to re-apply to the hospital if their pain increases. If a patient is coming from a remote distance, patients with AS $\leq 4$ should be hospitalized and monitored, and their AS should be calculated regularly. We concluded that some cases may be overlooked if patients with AS $\leq 4$ are discharged without clinical correlation. If surgery is not considered in the patients with AS $\leq 4$, we think that it would be appropriate to repeat the scoring at 3-4-hour intervals. Recurrent examinations may reduce morbidity in suspected patients.

With regard to the patients with AS 5-7, our results (75.9\%) of AA are comparable with those of Yildirim et al., ${ }^{[5]}$ who detected AA in $84.2 \%$ of their patients. We think that patients with AS 5-7 should be evaluated based on the clinical picture, scanning methods should be considered for young females, and a decision should be made by calculating AS at certain intervals.

With regard to the patients with AS 8-10, AA was detected in $91 \%$ of patients by Yildirim et al., ${ }^{[5]}$ in $86.5 \%$ by Khan et al., ${ }^{[13]}$ in $80.7 \%$ by Winn et al., ${ }^{[12]}$ and in $82 \%$ in the present study. The results were consistent with the literature. According to our results, reliability of AS is increased in the patients with AS of 8-10. This group of patients should undergo surgery without the need of other scanning methods. It should be kept in mind that morbidity, mortality and cost may increase in such patients if the surgery is delayed.

A negative appendectomy rate of $15-30 \%$ was found by Douglas et al., ${ }^{[2]} 6.8 \%$ by Jo et al., ${ }^{[14]} 32.5 \%$ by Menteş et al., ${ }^{[1]}$ and $19.4 \%$ in the present study. The distribution of negative appendectomy rates according to the three groups as AS $\leq 4$, AS 5-7 and AS 8-10 was not examined in the literature. According to Alvarado, a score of $\leq 6$ is significant in $80 \%$ of negative appendectomies. It is thought that using their scoring system, particularly in children and the elderly, would reduce the prevalence of negative appendectomy and perforation. In this study, negative appendectomy rates were found as $43.5 \%$ for AS $\leq 4,24$. I \% for AS $5-7$ and II \% for AS $8-10$, respectively.

Prevalence of negative appendectomy ranges between 15\% and $40 \%$ in the literature. ${ }^{[4,15-20]}$ Based on these data, prevalence of negative appendectomy in the AS $\leq 4$ group is beyond acceptable values. In the other groups, prevalence of negative appendectomy is reduced to more acceptable levels. However, as is known, operating on a patient with suspected AA and obtaining a negative appendectomy should not be considered as negativity.

No study in the literature has investigated the efficacy of the AS according to age, gender and BMI. The present study evaluated the efficacy of AS $(\leq 4,5-7,8-10)$ according to age, gender and BMI. The present study found no difference between genders in terms of the reliability of the AS in the AS $\leq 4$ group. The AS revealed more correct result in males in the AS 5-7 group. We think that male patients with AS 5-7 should undergo surgery without monitoring or using other auxiliary scanning methods, whereas female patients should be monitored or evaluated by other scanning methods. No difference was found between genders in the AS 8-10 group. In the present study, we observed no difference in terms of the reliability study performed by considering the age threshold as 40 years. Thus, AS can be used for evaluation of AA independent of age.

With regard to the $B M I$ reliability of the AS, a statistically significant result was found only for the AS 5-7 group. No statistically significant difference was found for the AS 8-10 group despite such close values as $79.5 \%$ and $88 \%$ (BMI $\leq 25$, $\mathrm{BMI}>25$, respectively) for those with AA. Considering overall cases, high BMI reduces the reliability of the AS.

Delayed treatment of AA prolongs the duration of hospitalization and return to normal life and increases the prevalence of perforation. ${ }^{[19,20]}$ The general perforation rate of AA was $20 \%$ according to Menteş et al. ${ }^{\left[{ }^{[I]}\right.}$ In the present study, the prevalence of perforated appendicitis was $7.7 \%$ in the AS $\leq 4$ group, $10 \%$ in the AS $5-7$ group, $27 \%$ in the AS $8-10$ group, and $20 \%$ in all cases. As seen in the Table, the prevalence of perforation increases as the AS increases. Although Douglas et al. ${ }^{[2]}$ defended surgical intervention as being non-essential in patients with $\mathrm{AS} \leq 4$, the present study detected perforation in one case $(7.7 \%)$ in this group. Therefore, we think that perforation may not be determined based on the AS. However, it is a fact that perforation is more likely in patients with a high AS. We believe there is a risk for perforation even when the AS is low, and such patients should undergo repeated $A S$ calculation.

In conclusion, in the present study, we investigated the efficacy of the Alvarado score in determining acute appendicitis. The results are summarized below:

I) Acute appendicitis may be detected in patients with AS $\leq 4$, and thus recommendations should be made while patients with AS $\leq 4$ are being discharged. 2) In patients with AS of 5-7, the efficacy of AS in detecting AA is lower in females than males. 3) In patients with AS of 5-7, the efficacy of AS in detecting appendicitis is higher in patients with BMI $<25$. 4) Evaluating the patient's age in conjunction with AS has no efficacy in detecting appendicitis.

\section{Conflict of interest: None declared.}

\section{REFERENCES}

1. Özuğur Ş. Klinik olarak şüpheli akut apandisitlerin değerlendirilmesinde Tc-99m HMPAO işaretli lökosit sintigrafisinin yeri. [Uzmanlık Tezi] Akdeniz Üniversitesi Tip Fakültesi Nükleer Tip Anabilim Dalı, Antalya 2001.

2. Douglas CD, Macpherson NE, Davidson PM, Gani JS. Randomised controlled trial of ultrasonography in diagnosis of acute appendicitis, incorporating the Alvarado score. BMJ 2000;321:919-22. CrossRef 
3. Poortman P, Oostvogel HJ, Bosma E, Lohle PN, Cuesta MA, de Langede Klerk ES, et al. Improving diagnosis of acute appendicitis: results of a diagnostic pathway with standard use of ultrasonography followed by selective use of CT. J Am Coll Surg 2009;208:434-41. CrossRef

4. Denizbasi A, Unluer EE. The role of the emergency medicine resident using the Alvarado score in the diagnosis of acute appendicitis compared with the general surgery resident. Eur J Emerg Med 2003;10:296-301.

5. Yildirim E, Karagülle E, Kirbaş I, Türk E, Hasdoğan B, Tekşam M, et al. Alvarado scores and pain onset in relation to multislice CT findings in acute appendicitis. Diagn Interv Radiol 2008;14:14-8.

6. Menteș O, Eryılmaz M, Harlak A, Oztürk E, Tufan T. The value of serum fibrinogen level in the diagnosis of acute appendicitis. Ulus Travma Acil Cerrahi Derg 2012;18:384-8. CrossRef

7. Schwartz S. Apendiks. In: Rosemay A, Rosly K, Rosly JJ, editors. Geçim İE. Cerrahinin ilkeleri. 7th ed. Ankara: AnTip; 2004. p. 1403-17.

8. Inci E, Hocaoglu E, Aydin S, Palabiyik F, Cimilli T, Turhan AN, et al. Efficiency of unenhanced MRI in the diagnosis of acute appendicitis: comparison with Alvarado scoring system and histopathological results. Eur J Radiol 2011;80:253-8. CrossRef

9. Pouget-Baudry Y, Mucci S, Eyssartier E, Guesdon-Portes A, Lada P, Casa $\mathrm{C}$, et al. The use of the Alvarado score in the management of right lower quadrant abdominal pain in the adult. J Visc Surg 2010;147:40-4. CrossRef

10. Ohle R, O'Reilly F, O'Brien KK, Fahey T, Dimitrov BD. The Alvarado score for predicting acute appendicitis: a systematic review. BMC Med 2011;9:139. CrossRef

11. Menteş Ö, Eryılmaz M, Yiğit T, Taşcı S, Balkan M, Kozak O, et al. Retrospectively analysis of appendectomies which performed elderly cases.
[Article in Turkish] Akademik Acil Tip Dergisi 2008;7:36-41

12. Winn RD, Laura S, Douglas C, Davidson P, Gani JS. Protocol-based approach to suspected appendicitis, incorporating the Alvarado score and outpatient antibiotics. ANZ J Surg 2004;74:324-9. CrossRef

13. Khan I, ur Rehman A. Application of alvarado scoring system in diagnosis of acute appendicitis. J Ayub Med Coll Abbottabad 2005;17:41-4.

14. Jo YH, Kim K, Rhee JE, Kim TY, Lee JH, Kang SB, et al. The accuracy of emergency medicine and surgical residents in the diagnosis of acute appendicitis. Am J Emerg Med 2010;28:766-70. CrossRef

15. Kamran H, Naveed D, Nazir A, Hameed M, Ahmed M, Khan U. Role of total leukocyte count in diagnosis of acute appendicitis. J Ayub Med Coll Abbottabad 2008;20:70-1.

16. Hernandez JA, Swischuk LE, Angel CA, Chung D, Chandler R, Lee S. Imaging of acute appendicitis: US as the primary imaging modality. Pediatr Radiol 2005;35:392-5. CrossRef

17. Chong CF, Thien A, Mackie AJ, Tin AS, Tripathi S, Ahmad MA, et al. Comparison of RIPASA and Alvarado scores for the diagnosis of acute appendicitis. Singapore Med J 2011;52:340-5.

18. Palabiyık F, Kayhan A, Cimili T, Toksoy N, Bayramoğlu S, Aksoy S. The comparison of plain film and ultrasound findings of appendicitis in children. [Article in Turkish] Marmara Medical Journal 2008;21:203-9.

19. Lintula H, Pesonen E, Kokki H, Vanamo K, Eskelinen M. A diagnostic score for children with suspected appendicitis. Langenbecks Arch Surg 2005;390:164-70. CrossRef

20. Lintula H, Kokki H, Kettunen R, Eskelinen M. Appendicitis score for children with suspected appendicitis. A randomized clinical trial. Langenbecks Arch Surg 2009;394:999-1004. CrossRef

\section{KLINIK ÇALIŞMA - ÖZET}

\section{Alvarado skoru akut apandisitte ne kadar güvenilir? \\ Dr. Yücel Yüksel, ${ }^{1}$ Dr. Bülent Dinç, ${ }^{2}$ Dr. Deniz Yüksel, ${ }^{3}$ Dr. Selcan Enver Dinç, ${ }^{4}$ Dr. Ayhan Mesci ${ }^{5}$}

${ }^{1}$ Tatvan Devlet Hastanesi, Genel Cerrahi Kliniği, Bitlis;

${ }^{2}$ Atatürk Devlet Hastanesi, Genel Cerrahi Kliniği, Antalya;

${ }^{3}$ Tatvan Devlet Hastanesi, Anesteziyoloji ve Reanimasyon Bölümü, Bitlis;

${ }^{4}$ Akdeniz Üniversitesi Tıp Fakültesi, Acil Tıp Anabilim Dalı, Antalya;

${ }^{5}$ Akdeniz Üniversitesi Tıp Fakültesi, Genel Cerrahi Anabilim Dalı, Antalya

AMAÇ: Bu çalışmada, Alvarado skorunun (AS) akut apandisiti (AA) saptamadaki güvenilirliği ve farklı parametrelerden ne oranda etkilendiği araştırıldı.

GEREÇ VE YÖNTEM: Akut apandisit şüphesi olan I8-70 yaş arası 313 hasta çalışmaya alındı. Acil serviste AS’leri hesaplanan hastaların taburcu, izlem ve ameliyat bilgileri kayıt edildi. Hastalar AS $\leq 4$, AS 5-7 ve AS 8-10 olmak üzere üç gruba ayrıldı. Farklı parametrelerde hastaların AA ve apendiks perforasyon oranlarına bakıldı.

BULGULAR: Hastaların (\%55 kadın, \%45 erkek) yaş ortalaması 30.8 \pm 10.8 idi. Ameliyat edilen 2 I I hastanın sırasıyla akut apendisit (apendiks perfo-

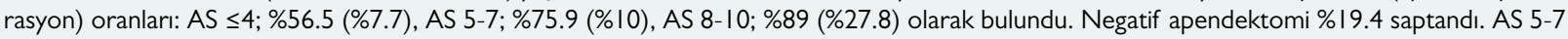
arası erkeklerde skorlama daha güvenilir olmakla birlikte tüm gruplarda beden kütle indeksi (BKI) arttıkça güvenilirlik azaldı.

TARTIŞMA: Alvarado skoru $\leq 4$ olan hastalar izlenmeli, taburcu edilen hastalar akut apandisit olabilecekleri hakkında bilgilendirilmelidir. AS'nin apandisiti saptamadaki etkisi, yaş ve semptomların başlama süresinden etkilenmemektedir.

Anahtar sözcükler: Alvarado skoru; apandisit; perforasyon; tanı.

Ulus Travma Acil Cerr Derg 2014;20(I):12-18 doi: 10.5505/tjtes.20 I4.60569 